\section{Mohammad Alharbi*}

Organization Imam Mohammad Ibn Saud Islamic University, Ministry of Higher Education, Saudi Arabia

Received: 30 April, 2019

Accepted: 03 June, 2019

Published: 04 June, 2019

*Corresponding author: Mohammad Alharbi, Medical College Al Imam Mohammad Ibn Saud Islamic University (IMSIU), Riyadh, Ministry of Higher Education, Saudi Arabia, Tel: 0555130575; E-mail: harbimbh@gmail.com

https://www.peertechz.com

Check for updates
Research Article

\section{Gallbladder Adenoumatous Polyps prevelance in Cholcystectomy in Saudi Arabia-cross sectional study}

\section{Abstract}

Introduction: Gallbladder polyps (GP), especially adenomatous, is quite rare. The prevalence of GP globally is variable, its importance comes from its potential to progress to gallbladder adenocarcinoma.

Methods: Cross sectional study of patients who had laparoscopic cholecystectomy, March 2009-sept 2017 in a community hospital in sulayel area in Saudi Arabia, to evaluate the prevalence of adenomatous gallbladder polyps in the pathology specimens.

Results: A total of 1205 patient have been examined ,the prevalence of adenomatous gallbladder polyps is approaching $(0.4 \%)$, no foci of malignancy were found.it is still below the international prevalence rate. 107 (8.9\%) patients with acute cholecystitis, 119 (9.9\%)acute on chronic cholecystitis, 11 (0.9\%) with complicated cholecystitis and $968(80.3 \%)$ patients with chronic cholecystitis.

Discussions: The prevalence of adenomatous gallbladder polyps is approaching $0.4 \%$, no foci of malignancy were found. It is still below the international prevalence rate.

Conclusion: Low prevalence rate of adenomatous gallbladder polyps compared to international levels may need further studies to explore the reasons behind.

\section{Introduction}

In general the prevalence of gallbladder polyp (GP) is increasing, with almost 6.1-8.7\% ,but overlong time follow up it proved that half of them will disappear $[1,2]$.

GP was significantly associated with old age, male gender, visceral obesity, but vegetarian on other hand has no association with GP $[3,4]$. GP has been reported to have association with colorectal adenoma [5]. Metabolic syndrome [6].

It is not clear that other diseases that have an association with GP will have a higher risk than others in population despite the association, but it seems they are independent from the primary disease, similar to primary sclerosing cholangitis, they benefit from cholecystectomy [7]. But patients with high Child-Pugh have a higher chance of early postoperative complications [8].

Association with stroke have been reported, but need more studies to explore this finding [9].

Some reports of GP being a metastasis from other organs, like renal cell carcinoma [10], or with lymphoma of gallbladder [11], carcinoid tumor [12,13].

Adenomatous polyps first described in literature by da costa et al. 1961 [14].

Yang et al., suggested a predictive pathway for GP which have higher chance for malignancy potentials, which will support the decision for malignancy [15]. Although Terzioglu et al., suggested patients with age above 60 , solitary polyps larger than $1 \mathrm{~cm}$, and sessile polyps to be associated with higher risk of cancer, and will require surgical removal [16-21]. Polyps less than $1 \mathrm{~cm}$ in size are not considered as a high risk of malignancy, but they may change over time [22,23]. With a necessity regular checkup [24]. It seems that polyps small than $6 \mathrm{~mm}$ are not required to have a regular check up [25]. Small lesions below $5 \mathrm{~mm}$ most of the time will not be identified in surgical specimen [26]. Unfortunately such clinical pathway was not considered in our facility due to limited expertise and small facility caliber.

\section{Methods}

We did cross-sectional study to evaluate how it is prevalent 
the gallbladder polyps, pathology reports of cholecystectomy between the years Mar 2009-Sept 2017, which were retrieved from 1205 patients from community hospital in the Saudi Arabia. Gross examination and microscopic examination have been assessed, pathology reports have been evaluated and included in the study. Further, cases without or missing report have been excluded from this study, such gallbladder cancer, xanthogranulomatous cholecystitis, cholesterolosis, and age below 12 years old, non-adenomatous gallbladder polyps.

\section{Result}

Distribution of gallbladder disease was calculated based on age, the youngest age was 13 and oldest was 88 years old. Patients were 106, 157 and 942 acute cholecystitis, acute on chronic cholecystitis, and chronic cholecystitis. With 925 female and 280 male, the median age was 35 years.

Prevalence of gallbladder adenomatous polyp with cholecystitis was $0.33 \%$ (4/1205). $107(8.9 \%)$ patient were with acute cholecystitis, $119(9.9 \%)$ with acute on chronic cholecystitis, 11 (0.9\%) with complicated cholecystitis (gangrenous, perforated, or empyema), and 968 (80.3\%) patients with chronic cholecystitis.

\section{Discussion}

Prediction of carcinogenesis of GP is important, yang et al., suggested that expression of MK-1, RegIV, others suggested ephrin-A7, metadherin, annexin A1 and A2, Msi1, ALDH1, enhancer of zesle homolog 2, and phosphatase and tension homolog, are closely related to carcinogenesis [27-31], unfortunately such advance studies are out of the scope of our facility capabilities.

Most of GP are non-neoplastic $85 \%$ (metaplastic $32 \%$ cholestrol $29 \%$, hyperplastic $22 \%$, inflammatory $2 \%$ ), and only $15 \%$ were adenoma [32]. Most of non-neoplastic polyps are in the proximal half of gallbladder, and most of the adenoma are in the distal half of gallbladder [32]. MaCain et al., suggested that only $5 \%$ pf GP are malignant or potentially malignant, then suggested more research to explore the decision making process of patients, who should go for cholecystectomy or for sequential radiological studies [33].

Cases which have been detected incidentally with cholecystectomy as dysplasia of gallbladder, without gross anomalies have not shown a major risk of hidden invasive adenocarcinoma [34]. Large lymphatic channels in in connective tissue of gallbladder at perimuscular zone explains why metastasis is high in T2 tumors of gallbladder cancer [35].

Multiple reports showed association between $\mathrm{h}$ pylori and cholecystitis, which raise the concern about its role to other gallbladder pathologies [36,37].

Endoscopic ultrasound should more accuracy than transabdominal ultrasound to differentiate neoplastic from nonneoplastic GP larger than $10 \mathrm{~mm}$, but it is not for lesions less than $10 \mathrm{~mm}$ [38]. Put in consideration that transabdominal ultrasound has a high false positive results approaching $86 \%$ [39].
Sometimes differentiating gallbladder cancer from GP is not easy preoperatively, but utilizing contrast enhanced ultrasound can make this goal approachable with acceptable sensitivity and specificity [40]. It was considered that size of GP of $1 \mathrm{~cm}$ is not strongly diagnostically accurate, and there is a need for surgical removal of gallbladder $[41,42]$. Put in consideration that most of GP are cholesterol GP [43]. Diffusion-weighted imaging is very helpful to differentiate gallbladder adenocarcinoma from adenoma, and predicting histologic grades of gallbladder adenocarcinoma [44].

Computed tomography can help if differentiating different types metastatic adenocarcinoma to gallbladder, but it is not that significant compared to GP [45].

It is considered symptomatic GP is beyond cure, which make too much concern to diagnose and predict early the sequelae of GP [46].

Laparoscopic cholecystectomy is the standard procedure which is a safe procedure, even single port procedure is acceptable for experienced surgeons [47,48], for polyps larger than $10 \mathrm{~mm}$, polyps between 5-10 mmm needs US study every 6 months twice, then it needs tailor according to the risk factors scan will need adjustment, and for $5 \mathrm{~mm}$ surveillance may be not required [49].

Wang et al., suggested doing polypectomy only, without cholecystectomy by using endolap (endoscopic laparoscopic technique) through experimental laboratory, which was successful and safe [50].

\begin{tabular}{|c|c|c|}
\hline Table 1: Distribution of the gallbladder disease finding after cholecystectomy. \\
\hline $\begin{array}{c}\text { Type of Disease } \\
\text { Acute cholecystitis }\end{array}$ & 107 & $8.9 \%$ \\
\hline $\begin{array}{c}\text { Acute on chronic } \\
\text { Chronic cholecystitis }\end{array}$ & 119 & $9.9 \%$ \\
\hline $\begin{array}{c}\text { Complicatedcholecystitis } \\
\text { (gangrenous,perforated,empyema) }\end{array}$ & 964 & $79.9 \%$ \\
\hline $\begin{array}{c}\text { Gallbladder adenomatous polyps } \\
\text { TOTAL }\end{array}$ & 11 & $0.9 \%$ \\
\hline
\end{tabular}

\section{References}

1. Heitz L, Kratzer W, Grater T, Schmidberger J (2019) Gallbladsder polyps - a follow-up study after 11 years. BMC Gastroenterol 19: 42. Link: https://bit.ly/2HSFUVC

2. Kratzer W, Schmid A, Akinli AS, Thiel R, Mason RA, et al. (2011) Gallbladder polyps: prevalence and risk factors. Ultraschall in der Medizin (Stuttgart, Germany: 1980) 32: S68-73. Link: https://bit.ly/2QEXpLX

3. Jo HB, Lee JK, Choi MY, Han IW, Choi HS, et al. (2015) Is the Prevalence of Gallbladder Polyp Different between Vegetarians and General Population? Korean J Gastroenterol 66: 268-273. Link: https://bit.ly/2HQbgMx

4. Lee JK, Hahn SJ, Kang HW, Jung JG, Choi HS, et al. (2016) Visceral Obesity Is Associated with Gallbladder Polyps. Gut Liver 10: 133-139. Link: https://bit.ly/2ZOsjkM 
5. Jeun JW, Cha JM, Lee Jl, Joo KR, Shin HP, et al. (2014) Association of gallbladder polyp with the risk of colorectal adenoma. Intest Res 12: 48-52. Link: https://bit.ly/2EQ8oNJ

6. Park EJ, Lee HS, Lee SH, Chun HJ, Kim SY, et al. (2013) Association between metabolic syndrome and gallbladder polyps in healthy Korean adults. J Korean Med Sci 28: 876-880. Link: https://bit.ly/2KIOJsJ

7. Torabi Sagvand B, Edwards K, Shen B (2018) Frequency, Risk Factors and Outcome of Gallbladder Polyps in Patients With Primary Sclerosing Cholangitis: A Case-Control Study. Hepatol Commun 2: 1440-1445. Link: https://bit.ly/2Wk5lbu

8. Eaton JE, Thackeray EW, Lindor KD (2012) Likelihood of malignancy in gallbladder polyps and outcomes following cholecystectomy in primary sclerosing cholangitis. Am J Gastroenterol 107: 431-439. Link: https://bit.ly/2Kvp6G7

9. Chen $\mathrm{CH}$, Lin $\mathrm{CL}, \mathrm{Kao} \mathrm{CH}$ (2015) Association of gallbladder polyp and stroke A nationwide, population-based study. Medicine (Baltimore) 94: e2192. Link: https://bit.ly/2YZdwqo

10. Shyr BU, Chen SC, Shyr YM, Lee RC, Wang SE (2017) Metastatic polyp of the gallbladder from renal cell carcinoma. BMC Cancer 17: 244. Link: https://bit.ly/2KIFPLL

11. Acharya V, Ngai J, Whitelaw D, Motallebzadeh R (2014) Primary gallbladder lymphoma presenting as a polyp. BMJ Case Rep 2014. Link: https://bit.ly/2XpneCi

12. Koizumi M, Sata N, Kasahara N, Morishima K, Kaneda Y, et al. (2011) Carcinoid tumor of the gallbladder: report of two cases. Clin J Gastroenterol 4: 323-330. Link: https://bit.ly/2ldzq2C

13. Mezi S, Petrozza V, Schillaci O, La Torre V, Cimadon B, et al. (2011) Neuroendocrine tumors of the gallbladder: a case report and review of the literature. J Med Case Rep 5: 334. Link: https://bit.ly/2HPJOJU

14. da C, Raposo JL (1961) Adenomatous polyp of the gallbladder. Archives des maladies de l'appareil digestif et des maladies de la nutrition 50: 176-186. Link: https://bit.ly/2Z6J9i1

15. Yang JI, Lee JK, Ahn DG, Park JK, Lee KH, et al. (2018) Predictive Model for Neoplastic Potential of Gallbladder Polyp. J Clin Gastroenterol 52: 273-276. Link: https://bit.ly/315Zup2

16. Terzioglu SG, Kilic MO, Sapmaz A, Karaca AS (2017) Predictive factors of neoplastic gallbladder polyps: Outcomes of 278 patients. The Turkish journal of gastroenterology: The official journal of Turkish Society of Gastroenterology 28: 202-206. Link: https://bit.ly/315JoLR

17. Guo J, Wu G, Zhou Z (2015) Polypoid lesions of the gallbladder: report of 160 cases with special reference to diagnosis and treatment in China International journal of clinical and experimental pathology 8: 11569-11578. Link: https://bit.ly/2JRUij9

18. Maciejewski P, Strzelczyk J (2014) Is gall-bladder polyp equivalent to cancer? An analysis of material from 1196 cholecystectomies--a comparison of the ultrasound and histopathological results. Pol Przegl Chir 86: 218-222. Link: https://bit.ly/2lfmrgK

19. Zemour J, Marty M, Lapuyade B, Collet D, Chiche L (2014) Gallbladder tumo and pseudotumor: Diagnosis and management. J Visc Surg 151: 289-300. Link: https://bit.ly/2WHqOui

20. Sarkut P, Kilicturgay S, Ozer A, Ozturk E, Yilmazlar T (2013) Gallbladde polyps: factors affecting surgical decision. World J Gastroenterol 19: 4526 4530. Link: https://bit.ly/2YXRJPY

21. Cha BH, Hwang JH, Lee SH, Kim JE, Cho JY, et al. (2011) Pre-operative factors that can predict neoplastic polypoid lesions of the gallbladder. World J Gastroenterol 17: 2216-2222. Link: https://bit.ly/2XmDBzx
22. Bhatt NR, Gillis A, Smoothey CO, Awan FN, Ridgway PF (2016) Evidence based management of polyps of the gall bladder: A systematic review of the risk factors of malignancy. Surgeon 14: 278-286. Link: https://bit.ly/2liR5Gb

23. Lu D, Radin R, Yung E, Tchelepi H (2015) Malignant transformation of a 5-mm gallbladder polyp over 2 years: a case report and review of current literature. Ultrasound quarterly 31: 66-68. Link: https://bit.ly/2Z5rIDT

24. Wiles R, Varadpande M, Muly S, Webb J (2014) Growth rate and malignant potential of small gallbladder polyps--systematic review of evidence. The surgeon: journal of the Royal Colleges of Surgeons of Edinburgh and Ireland 12: 221-226. Link: https://bit.ly/2HSFpLd

25. Pedersen MR, Dam C, Rafaelsen SR (2012) Ultrasound follow-up for gallbladder polyps less than $6 \mathrm{~mm}$ may not be necessary. Dan Med J 59 A4503. Link: https://bit.ly/2wFe74p

26. Konstantinidis IT, Bajpai S, Kambadakone AR, Tanabe KK, Berger DL, et al. (2012) Gallbladder lesions identified on ultrasound. Lessons from the las 10 years. Journal of gastrointestinal surgery: official journal of the Society for Surgery of the Alimentary Tract 16: 549-553. Link: https://bit.ly/2MnXPYz

27. Yang L, Lan S, Liu J, Yang Z (2011) Expression of MK-1 and RegIV and its clinicopathological significances in the benign and malignant lesions of gallbladder. Diagnostic pathology 6: 100. Link: https://bit.ly/2QFX9fN

28. Liu DC, Yang ZL (2011) Expression of ephrin-A7 and metadherin and its clinicopathological significances in the benign and malignant lesions of gallbladder. Zhonghua wai ke za zhi. Chinese journal of surgery 49: 250-255 Link: https://bit.ly/2JVpv55

29. Yang LP, Yang ZL, Tan XG, Miao XY (2010) Expression of annexin A1 (ANXA1) and A2 (ANXA2) and its significance in benign and malignant lesions of gallbladder. Zhonghua zhong liu za zhi 32: 595-599. Link: https://bit.ly/2JUHmsG

30. Liu DC, Yang ZL, Jiang S (2010) Identification of musashi-1 and ALDH1 as carcinogenesis, progression, and poor-prognosis related biomarkers for gallbladder adenocarcinoma. Cancer biomarkers: section A of Disease markers 8: 113-121. Link: https://bit.ly/2wyGVMf

31. Liu DC, Yang ZL, Yang LP (2008) Expression of enhancer of zesle homolog 2 and phosphatase and tension homolog and its clinicopathological significance in benign and malignant lesion of gallbladder. Zhong Nan Da Xue Xue Bao Yi Xue Ban 33: 618-622. Link: https://bit.ly/2Z4BRLO

32. Roa I, de Aretxabala X, Morgan R, Molina R, Araya JC, et al. (2004) Clinicopathological features of gallbladder polyps and adenomas. Rev Med Chil 132: 673-679. Link: https://bit.ly/2WO2yHb

33. McCain RS, Diamond A, Jones C, Coleman HG (2018) Current practices and future prospects for the management of gallbladder polyps: A topical review. World J Gastroenterol 24: 2844-2852. Link: https://bit.ly/2WDPjlJ

34. Rais R, Gonzalez I, Chatterjee D (2019) Dysplasia in Gallbladder: What Should We Do? J Gastrointest Surg 23: 686-689. Link: https://bit.ly/2KplQvF

35. Nagahashi M, Shirai Y, Wakai T, Sakata J, Ajioka Y, et al. (2007) Perimuscular connective tissue contains more and larger lymphatic vessels than the shallower layers in human gallbladders. World J Gastroenterol 13: 44804483. Link: https://bit.ly/2Z2q8x8

36. Chen DF, Hu L, Yi P, Liu WW, Fang DC, et al. (2007) H pylori are associated with chronic cholecystitis. World J Gastroenterol 13: 1119-1122. Link: https://bit.ly/2HTBIKU

37. Monstein HJ, Jonsson Y, Zdolsek J, Svanvik J (2002) Identification of Helicobacter pylori DNA in human cholesterol gallstones. Scand $J$ astroenterol 37: 112-119. Link: https://bit.ly/2KmKDkc

38. Pack HS, Cheon YK, Shim CS, Lee TY (2016) Comparative Study of Endoscopic Ultrasonography with Transabdominal Ultrasonography in the Diagnosis 
for Polypoid Lesion of Gallbladder. Clinical Ultrasound 1: 39-45. Link: https://bit.ly/2ENRcZm

39. Martin E, Gill R, Debru E (2018) Diagnostic accuracy of transabdominal ultrasonography for gallbladder polyps: systematic review. Can J Surg 61: 200-207. Link: https://bit.ly/2WAEzLm

40. Miwa H, Numata K, Sugimori K, Sanga K, Hirotani A, et al. (2019) Differentia diagnosis of gallbladder polypoid lesions using contrast-enhanced ultrasound. Abdom Radiol (NY) 44: 1367-1378. Link: https://bit.ly/2MAgfVU

41. Wennmacker SZ, van Dijk AH, Raessens JHJ, van Laarhoven C, Drenth JPH et al. (2018) Polyp size of $1 \mathrm{~cm}$ is insufficient to discriminate neoplastic and non-neoplastic gallbladder polyps. Surg Endosc 33: 1564-1571. Link: https://bit.ly/2WqiRdT

42. Oestmann A (2012) Polyps of the gallbladder. Praxis (Bern 1994) 101: 581 584. Link: https://bit.ly/2WgqPpA

43. Bugosen Tannous M, Tagle Arrospide M, Huerta-Mercado Tenorio J, Scavino Levy Y (2011) Gallbladder polyps: Clinical and pathological features in Cholecystectomy patients in the Anglo American clinic in the period of 19992007]. Revista de gastroenterologia del Peru: organo oficial de la Sociedad de Gastroenterologia del Peru 31: 32-37. Link: https://bit.ly/2XquHRu

44. Lee NK, Kim S, Moon Jl, Shin N, Kim DU, et al. (2016) Diffusion-weighted magnetic resonance imaging of gallbladder adenocarcinoma: analysis with emphasis on histologic grade. Clinical imaging 40: 345-351. Link: https://bit.ly/2ld6kAp

45. Choi WS, Kim SH, Lee ES, Lee KB, Yoon WJ, et al. (2014) CT findings of gallbladder metastases: Emphasis on differences according to primary tumors. Korean J Radiol 15: 334-345. Link: https://bit.ly/2JVqPF5

46. Andren-Sandberg A (2012) Diagnosis and management of gallbladder polyps. N Am J Med Sci 4: 203-211. Link: https://bit.ly/2JSYor9

47. Qiu Z, Sun J, Pu Y, Jiang T, Cao J, et al. (2011) Learning curve of transumbilical single incision laparoscopic cholecystectomy (SILS): a preliminary study of 80 selected patients with benign gallbladder diseases. World J Surg 35: 2092 2101. Link: https://bit.ly/2HSJHSQ

48. Kubota K, Bandai Y, Otomo Y, Ito A, Watanabe M, et al. (1994) Role of laparoscopic cholecystectomy in treating gallbladder polyps. Surg Endosc 8: 42-46. Link: https://tinyurl.com/y35bxyg5

49. Babu BI, Dennison AR, Garcea G (2015) Management and diagnosis of gallbladder polyps: a systematic review. Langenbeck's archives of surgery 400: 455-462. Link: https://tinyurl.com/y4l716vf

50. Wang J, Tan Y, Zhao G, Wang D, Ji Z (2014) A new exploration for gallbladder polyps: gallbladder polypectomy by endolap technique. Journal of laparoendoscopic \& advanced surgical techniques 24: 852-857. Link: https://tinyurl.com/yxe2kc6j

\section{Discover a bigger Impact and Visibility of your article publication with} Peertechz Publications

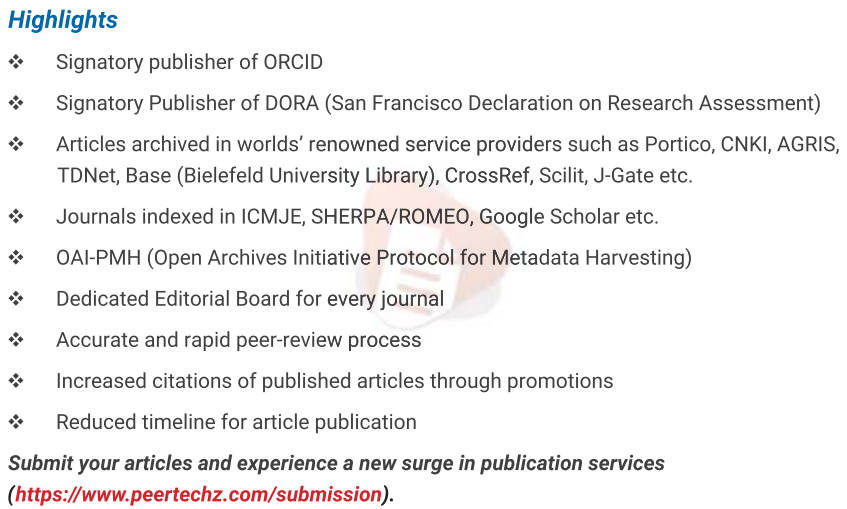

Peertechz journals wishes everlasting success in your every endeavours.

Copyright: (c) 2019 Alharbi M. This is an open-access article distributed under the terms of the Creative Commons Attribution License, which permits unrestricted use, distribution, and reproduction in any medium, provided the original author and source are credited. 